\title{
METAL NANOPARTICLES - THEIR USE AND IMPACT ON PLANTS GROWING IN LABORATORY CONDITIONS
}

\author{
Department of Genetics, Plant Breeding and Biotechnology, West Pomeranian University \\ of Technology, Szczecin, Poland
}

\begin{abstract}
There is an increasing interest in nanotechnology all around the world. Nanoparticles differ from the classic material from which they are made in that they change their physical and chemical properties below certain sizes. Thanks to these properties, they are used both in scientific research, medicine and industry, and in recent years also in agriculture. Depending on the type of metal and size of the particules, however, their impact on plant development varies. There are different reports concerning the impact of nanoparticles on the growth and development of plants. In this paper, we gather the knowledge acquired up to now on the interactions of specified nanoparticles - of gold, silver, copper and platinum with plants cultivated in laboratory conditions. The existing research does not allow us to determine unequivocally what impact nanometals have on the plants. The properties that make them unique may have both a negative and positive impact on plants. In a great deal of research, the impact of the nanoparticles on the decrease of the plants' growth and formation of sorter shoots and roots was observed. A high concentration of nanoparticles was also decreasing the chlorophyll content, photosynthesis, transpiration and stomatal conductance rates. The contact of plants with nanoparticles was also manifesting itself by an increased oxidative stress, as a result of which in plant tissues, an over-production of reactive oxygen species damaging lipids of the cell membrane and the DNA was observed. A slower regeneration of plants and their dieback was frequently observed in the case of the addition of nanoparticles to nutrient mediums in the in vitro cultures. By carrying out a series of research with the use of nanoparticles, researchers concluded that their appropriate concentrations may be used in order to improve seed germination, increase growth and plant production as well as their protection and improvement of production of bioactive compounds.
\end{abstract}

Key words: nanotechnology, metal nanoparticles, regeneration of plants.

\section{INTRODUCTION}

Nanoparticles with at least one dimension contained within the range from 1 to $100 \mathrm{~nm}$ are atomic or molecular aggregates, often having different physico-chemical properties as compared to its macroscopic particles (Ball 2002; Roco 2003b; Nel et al. 2006). The nanoparticles show different effects depending on both the chemical composition and size and/or the particles' size (Brunner at al. 2006) The nanoparticles are divided into three types: natural, which may occur in the form of such materials as, e.g. volcanic ash and lunar dust, mineral components formed accidentally as unintended by-products of anthropogenic processes and designed, i.e. intentionally developed and created by a human having in mind

Corresponding author: Danuta Kulpa, Department of Genetics, Plant Breeding and Biotechnology, West Pomeranian University of Technology, Szczecin, Juliusza Słowackiego 17, 71-434 Szczecin, Poland, e-mail: Danuta.Kulpa@zut.edu.pl 
their application possibilities (Monica and Cremonini 2009). Metal nanoparticles (MNPs) belong mainly to the third nanoparticle type. They have not only unique physical and chemical properties (e.g. a higher surface-to-volume ratio, an atypical surface structure, a higher reactivity), but also an impact on biological tissues. Thanks to these features, they are used in commercial products more and more often, including, among others, in the production of medications, cosmetics and as transporting particles (Nowack and Bucheli 2007; Roco 2003a). They are also used in optoelectronics, nanodevices, nanoelectronics and nanosensors. Their antibacterial properties are used in medical devices and equipment, water treatment and food processing (Ramyadevi et al. 2012). Metal-based nanoparticles (NPs) include zero-value metal nanoparticles (e.g. Au, Ag, Fe NPs), nano-metal oxides (e.g. nano- $\mathrm{ZnO},-\mathrm{TiO} 2$ etc.) and nano-metal salts (e.g. nanosilicates and ceramics) (Torney et al. 2007; Mauter and Elimelech 2008; Barnard 2010).

\section{APPLICATION OF NANOPARTICLES IN INDUSTRY}

Nanosilver, due to its antimicrobial properties, is applied more and more both in industry and medicine (Nowack et al. 2011; Chen and Schluesener 2008). The interest in silver had begun already in antiquity when it started to be considered as having healing and disease-preventing properties. The Ancient Greeks were using dressings containing silver in order to stimulate the healing process, and they were keeping water in silver vessels (Alexander 2009; Murr 2009). During World War I, this metal was a basic antiseptic substance applied to combat wound infections, due to a vast range of antimicrobial properties (Chen and Schluesener 2008). It was the most important substance available before the introduction of antibiotics.

Nanoparticle silver, just like its macroscopic equivalent, has a series of advantages, i.e. chemical stability, thermal conductivity, catalytic and antibacterial activity (Vaidyanathan et al. 2009). The research confirms the antibacterial effects of the silver nanoparticles resulting from a high fraction of surface atoms-higher than macroscopic silver. The change in the form and density of surface atoms has an impact on the change of their reactivity. AgNPs have an increased affinity to the cell membranes and an increased ion propagation rate, which leads to an increase in antibacterial activity (Bansal et al. 2010). The research of Sondi and Salopek-Sondi (2004) confirms that silver nanoparticles provide excellent antibacterial activity against Escherichia coli. The bacterial cells are damaged through "cavities" formed in the cell membrane that lead to a significant increase in permeability and, as a consequence, in the cell's death.

Copper, like silver, is a well-known antimicrobial material. It is believed that these metals react with proteins through bonding - $\mathrm{SH}$ enzymes groups, which, as a result, leads to protein inactivation (Jeon et al. 2003). Yoon et al. (2007) described the antibacterial effects of silver and cooper nanoparticles with the use of single representative Escherichia coli and Bacillus subtilis strains, where copper nanoparticles were manifesting better antibacterial activity as compared to silver nanoparticles. Also, Cioffi et al. (2005) proved the bacteriostatic activity of copper nanocomposites towards microorganisms, i.e. Escherichia coli, Staphylococcus aureus and Lysteria monocytogenes. The research of Ruparelia et al. (2008), comparing the 
effects of silver and copper components, showed that they are very promising as an antibacterial substance against Eschericha coli, Bacillus subtilis and Staphylococcus aureus. The tests proved that the antimicrobic effects of silver nanoparticles, in the case of Escherichia coli and Staphulococcus aureus, was better than in the case of copper; on the other hand, the cooper nanoparticles presented better activity towards Bacillus subtilis. In the research of Ramyadevi et al. (2012), copper nanoparticles were presenting antibacterial activity towards the studied pathogenic strains of Micrococcus luteus, Staphylococcus aureus, Escherichia coli, Klebsiella pneumoniae, Pseudomonas aeruginosa, as well as towards fungi: Aspergillus falvus, Aspergillus niger and Candida albicans. The nanoparticles were manifesting a higher activity in the interaction with bacteria rather than with fungi. The copper nanoparticles also have catalytic, optical and electrical properties. They have been applied in the production of plastic materials used in medicine (Mary et al. 2009).

Nanogold also is a material with a wide range of applications. It is used, among others, in nanoelectronics, catalysis and in the construction of biological sensors (Zhou et al. 2005). The size of a gold nanoparticle (AuNPs) has a huge impact on its physical and chemical properties. As compared to macroparticle gold, AuNPs have a lower melting temperature, red color and a higher number of surface atoms. It is caused by a reduction in the diameter of the particles, which increases the share of surface atom fraction as compared to the core atoms' fraction. This is illustrated the best by the comparison of nanoparticles $\varnothing \approx 100 \mathrm{~nm}$, for which the surface fraction constitutes $6 \%$ of the total amount of atoms with nanoparticles $\varnothing \approx 5 \mathrm{~nm}$, where it already reaches about $78 \%$ of all atoms (Schmid and Corain 2003; Vázquez-Victorio et al. 2013). The gold-based nanomaterials (AuNPs) are characterised by a controlled size dispersion, stability, higher adsorption properties and good optical properties (Lee et al. 2010). Its most important property is the catalytic activity concerning both the organic compounds and non-organic compounds. Nanogold is also used in biomedicine and pharmacy. In immunohistochemistry, these nanoparticles are applied in the construction of electrochemical immunosensors in which they fulfil a major role in the improvement of electrochemical signal quality (Wang et al. 2004). In the research of Grace and Pandian (2007), gold nanoparticles were used as a probe for the detection of aminoglycoside antibiotics, i.e. streptomycin, gentamicin and neomycin. The results also confirmed that the gold nanoparticles may act as an effective medium of active substances, because they are small enough to reach target tissues and cells. They also have the ability to improve the solubility of medications, and they also improve stability within the body. Further research also demonstrated that the combination of antibiotics and gold nanoparticles is effective both for Gram-positive bacteria (Staphulococcus aureus, Micrococcus luteus) and Gram-negative bacteria (Escherichia coli, Pseudomonas aeruginosa). The antibacterial activity of medications coated with gold nanoparticles was higher than the activity of non-coated medications.

Along with the development of the nanotechnology of noble materials, nanoplatinum has attracted researchers' attention. It is used both as a heterogenic and homogenic catalyst of chemical reactions, i.e. hydrogenation, hydration and oxidation. It is possible thanks to a high surface-to-volume ratio and a high surface energy (Narayanan and El-Sayed 2005). In the most recent research, we observe the usefulness of platinum in the treatment of neoplastic diseases. A significant, depending on the dose, decrease of the cells' viability was observed 
along with an increase in the concentration of nanoparticles. It is related to the ability of the small particles of this metal $(5-6 \mathrm{~nm})$ to breach the DNA structure, leading to an apoptosis (Kostova 2006; Asharani et al. 2010; Manikandan et al. 2013).

It is estimated that in 2010 in different branches of industry, about 200 tonnes of nanoparticles were produced. A rapidly growing interest in nanomaterials raised questions concerning the potentially negative effects to the environment and human health. The nanomaterials released into the environment are deposited in the soil and water in large quantities, and they have an impact on the environment. The target effects of the compounds is not entirely known (Benn and Wasterhoff 2008; Kaegi et al. 2010; Gottschald and Nowack 2011).

\section{THE IMPACT OF METAL NANOPARTICLES ON THE DEVELOPMENT OF PLANTS:}

Metals fulfil a major role in the metabolic pathway during the growth and development of plants. The process in which the plant system enters into an interaction with nanometals may be explained through a simple model: starting from the source of the emission, nanometals are transported through different media and eventually enter into an interaction with the plants' rhizosphere (soil, water) and/ or with the plants' phyllosphere (the air) (de la Rosa et al. 2017). At the moment of contact with a plant, the nanoparticles penetrate into the cell walls and membranes of the root peels, and then they move simplistically to steles and leaves through the xylem. However, in order to pass through the intact cell membrane, the NPs move around through pores on the cell membrane, which indicates that the uptake of nanomaterial is depending on the size (Ma et al. 2010a, b; Rico et al. 2011). The NPs uptake mechanism is generally considered as a mechanism of active transport that includes several other cellular processes, such as signalling, recycling and regulation of the cell membrane (Etxeberria et al. 2009). After overcoming the root barrier, the diameter of the xylem defines the permissible size of the transported nanoparticles and the water transportation rate, which may be significantly related to the kinetics of nanomaterial transportation in plants' systems (Ma et al. 2010a).

The majority of research demonstrated a certain degree of phytotoxicity of nanoparticles, in particular in high concentrations (Miralles et al. 2012). Wang et al. (2016) observed that Arabidopsis thaliana (L.) plants growing in the soil treated with ZnONPs have lower growth, chlorophyll content and a reduced photosynthesis rate. These effects were dependent on the concentration. The growth of the plants growing in the soil with 200 and $300 \mathrm{mg} \cdot \mathrm{dm}^{-3}$ of ZnONPs was, respectively, 20 and $80 \%$ as compared to the control plants. Among the plants growing in the soil with $300 \mathrm{mg} \cdot \mathrm{dm}^{-3}$ of ZnONPs, the chlorophyll content, photosynthesis rate, stomatal conductance of the leaves, intercellular $\mathrm{CO}_{2}$ concentration and transpiration rate were reduced by more than $50 \%$. The researchers also stated an inhibition of the expression of genes involved in chlorophyll synthesis and the photosystem structure.

Da Costa and Sharma (2016), while studying the impact of $1000 \mathrm{mg} \cdot \mathrm{dm}^{-3}$ of CuONPs on Oryza sativa (L.), observed a decrease in the photosynthesis rate, transpiration rate, stomatal conductance rate, the maximum quantum yield of PSIl photochemistry and in the content of photosynthetic pigments. The CuONPs accumulation in chloroplasts was accompanied by a lower number of thylakoids per granum. 
Apart from a reduced photosynthesis rate, the inhibition of growth caused by NPs is also related to an increased oxidative stress (Da Costa and Sharma 2016). The oxidative stress was observed many times among plants exposed to toxic levels of NPs (Thwala et al. 2013; Hossain et al. 2015). The exposure to different NPs, for example $\mathrm{Ag}, \mathrm{ZnO}$ and $\mathrm{Al}_{2} \mathrm{O}_{3}$ (alumina), induced a production of reactive nitrogen species ( ${ }^{*} \mathrm{NO}$, nitric oxide) and $\mathrm{H}_{2} \mathrm{O}_{2}$ among water lens (Thwala et al. 2013), corn (Zhao et al. 2012) and tobacco (Poborilova et al. 2013). A common consequence of the high ROS levels is damage to the cellular macromolecules, including lipids of the cell membrane that lead to the cells' death (Van Breusegem and Dat 2006). After an increase in the ROS quantity, the stress leads to the impairment of organelle function, membrane and eventually to phytotoxicity (Sharma et al. 2012; Kumar et al. 2013). The inhibition of growth in combination with lipid peroxidation was observed in Oryza sativa seedlings treated with 0.5, 1 and $1.5 \mathrm{mM}$ CuONPs (Shaw and Hossain 2013). NPs also damaged other macroparticles such as DNA. AgNPs and AuNPs also inhibited the divisions of cells in the root core of the common onion (Rajeshwari et al. 2016).

In the research of Rui et al. (2017) with the use of Arachis hypogea plants, in which a sandy soil was used as nutrient medium, an addition in the form of silver nanoparticles caused an inhibition of the plants' growth, a decrease in their mass, an increase in the enzyme content and their antioxidant activity, as well as a change in the fatty acids content.

Zuverza-Mena et al. (2016) defined the impact of silver nanoparticles on the physiology and nutrients of radish sprouts (Raphanus sativus). The studied concentration had no impact on the germination ability of the seeds. On the other hand, the water content, the roots' and shoots' length and the content of $\mathrm{Ca}, \mathrm{Mg}, \mathrm{B}, \mathrm{Cu}, \mathrm{Mn}$ and $\mathrm{Zn}$, proteins, lignin, pectin and cellulose have decreased.

In order to alleviate the consequences of oxidative stress and to remove the excessive ROS, the plants activate both enzymatic and non-enzymatic defence processes related to the production of antioxidants. Thus, the treatment of plants with nanoparticles has an impact on the stress occurrence among plants, which in response increases the antioxidant content in tissues (Sewelam et al. 2016). It results from the research that the ROS homoeostasis disturbance impairs the growth and development of plants; however, the maintenance of ROS on a low, harmless level (which entails an induction of the antioxidant processes by NPs.) may favour their growth (Mittler 2002).

The researchers studied the impact of nanoparticles on the germination and growth of the plants, aiming to define their application possibilities in agriculture. The obtained research results were divergent. Some results confirmed that nanoparticles may cause phytotoxicity and have a negative impact on the germination and growth of the seeds, but other researchers stated, on the other hand, that nanometals in appropriate concentrations may be applied in order to improve the germination of the seeds, increase the growth and the plant yield, as well as their protection and improvement of the production of bioactive compounds (Khot et al. 2012). Fazal et al. (2016) observed a stimulating impact of nanoparticles on the proliferation of callus in a culture of a plant form Prunella vulgaris species. Savithramma et al. (2012) confirmed the stimulating effects of silver on the germination of the seeds of a plant from the Boswellia ovalifoliolata species. This effect was most likely related to the impact of metal on the mechanism of the penetration of water and nutrients to the seeds. 
The existing research demonstrated that NPs have both a positive and negative impact on the different biological functions of the plants (Navarro et al. 2008; Rico et al. 2011). The toxicity degree of nanoparticles depends on the manner of obtaining them. It was proved that biogenic AgNPs present relatively fewer toxic effects than their chemically synthesized equivalents (Rani and Rajasekharreddy 2011).

\section{THE USE OF SILVER NANOPARTICLES IN THE IN VITRO CULTURES}

In vitro plant cultures, that is to say, plant cultures conducted on artificial, sterile nutrient media, allow for studying plants in strictly-controlled conditions. Most often the cultures are kept in Petri dishes, conical flasks or in culture tubes. This method fulfils an important role in the basic research, mainly in the field of physiology, biochemistry and plant molecular biology. The explants are cultivated on nutrient media with added mineral compounds, energy and carbon sources, vitamins, organic nitrogen and growth regulators. A plant in the in vitro culture does not conduct the photosynthesis process. Thanks to ensuring the abovementioned conditions, it is possible to strictly control the addition of metal nanoparticles and their impact on the plant.

In most cases, the addition of nanosilver to the growth medium caused an inhibition of the growth and development of the studied plants (Homaee and Ehsanpour 2015; Nair and Chung 2015; Rani et al. 2016; Sosan et al. 2016; Mubashir et al. 2017; Rui et al. 2017). However, in the experiment of Homaee and Ehsanpour (2015) aside from a negative impact on the shoots' length, the addition of nanoparticles caused an improvement of the growth parameters such as dry matter, roots' length and leaves' size in potato (Solanum tuberosum) cultivated in the in vitro cultures. Moreover, an increase in the chlorophyll and carotenoid content, as well as a decrease in the phenol content, were observed. The positive effects of silver were also demonstrated by Fazal et al. (2016). In the experiment of Shokri et al. (2013) on Rosa hybrida (L.), nanosilver was added to a nutrient medium with concentrations of $0,50,100$ and $150 \mathrm{ppm}$. The results showed that the concentration of $100 \mathrm{ppm}$ in the medium may decrease the risk of bacterial contamination and the phenol secretion rate. On the other hand, high concentrations of nanosilver slowed down the regeneration of explants and, in some cases, it led to their dieback. In another experiments, the explants were immersed in nanosilver solutions with concentrations of 0, 100, 200 and $400 \mathrm{ppm}$. The concentration of $200 \mathrm{ppm}$ for $20 \mathrm{~min}$. after surface sterilisation was the best control method of bacterial contamination. Nanosilver had no impact on contamination with fungi.

Mehrian et al. (2015) studied the impact of silver nanoparticles on the content of free amino acids and the antioxidant defence system of tomato (Lycopersicon esculentum) multiplied in the in vitro cultures. The results showed that the concentration of amino acids in tomatoes was increasing along with an increase of silver nanoparticles. The highest growth of amino acid content was observed at concentrations 75 and $100 \mathrm{mg} \cdot \mathrm{dm}^{-3}$. The highest growth was observed in the case of glutamine and asparagine. Along with an increase in the nanosilver concentration, the total soluble protein was decreasing, and the SOD, CAT and POX activity in shoots and roots was increasing. Also, the malondialdehyde concentration was increasing. 
Rani et al. (2016) studied differences in the impact of chemically created (S-AgNPs) and biologically created (B-AgNPs) metal nanoparticles on water plants. The water hyacinth (Eichhornia crassipes) was used in the research. Among the plants treated with S-AgNPs, an inhibition of growth, a higher concentration of nanometal and an increase of phenols and the chlorophyll content in the leaf extract were observed. The activity of antioxidant enzymes such as catalase, peroxidase and superoxide dismutase has also increased. An increased concentration of carbohydrates and proteins as well as a decreased phenol and chlorophyll content was observed among plants treated with B-AgNPs.

Sosan et al. (2016), using a model plant, Arabidopsis thaliana, determined an interaction between AgNPs and plant cells and their physiological roles. The AgNPs addition to the nutrient medium in concentrations higher than $300 \mathrm{mg} \cdot \mathrm{dm}^{-3}$ inhibited the extension of roots and growth of the leaves. It also resulted in a decreased efficiency of photosynthesis and AgNPs accumulation within the tissues. A transitional increase in calcium ions and an accumulation of reactive oxygen species in cells were also observed. The research demonstrated the impact of AgNPs on the exchange of potassium and calcium ions in the cell membrane leading to its disintegration. Li et al. (2018), using the same plant, studied the impact of silver nanoparticles in combination with a popular herbicide (Diclofop-methyl - DM). The research demonstrated an inhibiting impact of AgNPs on the growth of plants and chlorophyll synthesis and a higher damage related to the oxidative stress among plants treated only with nanometal in comparison to the plants, in the case of which the DM was additionally used. An increase in the relative level of gene transcripts related to the photosynthesis was observed among plants treated with both compounds at the same time. This may result from the fact that the presence of DM has an impact on the stability of AgNPs and a decrease in $\mathrm{Ag}+\mathrm{z}$ AgNPs release in the mixture.

In the research of Nair and Chung (2014) studying rice seedlings (Oryza sativa L.), a significant inhibition of the roots' growth, a decrease in the plant dry matter and in the total chlorophyll and carotenoids content were observed. An addition to AgNPs, nutrient medium in concentrations amounting to 0.5 and $1.0 \mathrm{mg} \cdot \mathrm{dm}^{-3}$ caused a significant increase in the hydrogen peroxide concentration and lipid peroxidation in shoots and roots, an increased proline accumulation within the leaves and a decreased sugar content. The exposure to AgNPs caused an increase in the production of reactive oxygen species and an increased cytotoxicity dependent on the dose. It was demonstrated in tests that, along with an increase in nanometal concentration, the membrane potential of mitochondria was decreasing. A difference in the transcription of genes related to the oxidative stress tolerance was stated. The same researchers conducted a similar experiment using Mung beans (Vigna radiata), and they confirmed the results that they obtained using rice seedlings, i.e. a decrease in the length of the shoots and roots, a decrease in the fresh plant matter, a decrease in the chlorophyll content, an increase in proline content, an increase in the hydrogen peroxide level, in the lipid peroxidation and in the production of reactive oxygen species. Also, in this case, the PCR analyses demonstrated changes in the relative mRNA expression of genes, indicating antioxidant defence responses of the plants in stress conditions. 


\section{THE IMPACT OF GOLD NANOPARTICLES ON THE GROWTH OF PLANTS IN THE IN VITRO CULTURES}

Like silver, gold also shows a significant impact on the growth and development of plants in the in vitro cultures. Arora et al. (2012) studied the impact of gold nanoparticles on the growth and development of the Brassica juncea plant. A positive impact of AuNPs was observed in the case of the plants' height, the stem's diameter, the number of shoots, the number of pods and the seed yield. The number of leaves has also increased, but no impact on their surface has been observed. The best seed germination index was observed in the case of the treatment of plants with $10 \mathrm{ppm}$ AuNPs. The content of reducing sugars and the total sugar content increased at the concentration of $25 \mathrm{ppm}$ AuNPs. Application of AuNPs also improved the redox status of the treated plants. Gunjan and Zaidi (2014) also defined an interaction between AuNPs and Brassica juncea in the in vitro cultures. The research results were showing an overall growth inhibition related to the occurrence of an oxidative stress. As a consequence of the cumulation of reactive oxygen species, the concentration of antioxidant enzymes, proline and hydrogen peroxide has also increased. The inhibition of growth and the development of the plants, as well as a significant increase in the activity of antioxidant enzymes were also observed by Mubashir et al. (2017) in their research on Artemisia absinthium. A reduction of the length of the shoots, roots and fresh plant matter, as well as a cumulation of the reactive oxygen species was also observed in Vigna radiata plants studied by Nair and Chung (2015). Fazal et al. (2016) in their research on Prunella vulgaris demonstrated a positive impact of gold on the proliferation of callus. Moreover, gold increased the protein content in callus and the concentration of superoxide dismutase (SOD) and peroxidase (POX). Feichtmeier et al. (2015) defined the impact of AuNPs on barley seeds (Hordeum vulgare L.). For this purpose, the seeds were cultivated on a nutrient medium enriched in given nanoparticles, and then they were transferred onto nutrient media without them. The research results indicated an accumulation of AuNPs in the plants' roots. An impact on the uptake of micro- and macro-elements from the nutrient medium, the biomass production and the roots' development dependent on the concentration of nanometals was observed. Despite the fact that the regeneration of plants was not affected to a large extent, the roots' length was decreased. Ostroumov et al. (2014) studied the interactions of gold nanoparticles (AuNPs) with water macrophytes (Ceratophyllum demersum). In the research, the phytotoxicity of gold nanoparticles for water macrophytes was demonstrated for the first time. The result of the experiment was the necrosis of $20 \%$ of the culture.

\section{THE IMPACT OF COPPER NANOPARTICLES ON THE INCREASE OF PLANTS IN THE IN VITRO CULTURES}

Within the last few years, copper nanoparticles (CuNPs) have been generating a growing interest among researchers. Its impact on plant cultures in vitro was defined by Lee et al. (2008) in the research on Phaseolus radiatus and Triticum aestivum, Nair and Chung (2014) and Pradhan et al. (2015) in the research on Vigna radiata, Shi et al. (2014) in the research on Elsholtzia splendens, Mubashir et al. (2017) in the research on Artemisia absinthium, Du 
et al. (2018) in the research on Origanum vulgare, Adams et al. (2017) in the research on wheat seedlings, Javed et al. (2017) in the research on Stevia rebaudiana, Trujillo-Reyes et al. (2014) in the research on Lactuca sativa and Zuverza-Mena et al. (2015) in the research on Coriandrum sativum.

Lee et al. (2008), Nair and Chung (2014), Shi et al. (2014), Zuverza-Mena et al. (2015), Mubashir et al. (2017), Du et al. (2018) observed morphological changes (a negative impact on the length and/or biomass of the plants) among plants caused by the impact of copper nanoparticles as compared to the control plants. In the research of Trujillo-Reyes et al. (2014) and Adams et al. (2017), an inhibition of the roots' extension was observed. Only in the research of Pradhan et al. (2015) neither cytotoxicity nor morphological and physiological changes were observed.

In the experiment of Lee et al. (2008), the height of the seedlings of plants from Phaseolus radiatus and Triticum aestivum species was negatively related to the CuNPs concentration. In the research of Nair and Chung (2014), a consequence of the addition of copper nanoparticles to the nutrient medium also had an increase in the content of hydrogen peroxide and lipid peroxidation in the roots, a reduction of chlorophyll concentration, a significant increase in the proline concentration and a concentration-dependent increase in the production of reactive oxygen species in the roots. Mubashir et al. (2017) observed an inhibition of the growth and development of plants, as well as a high stressor activity of copper and its impact on the increase of the total phenol and flavonoids contents. Shi et al. (2014) observed an inhibition of the plant growth. CuNPs-like deposits were found in the cells of roots and leaves among the plants treated with copper nanoparticles at a concentration of $1000 \mathrm{mg} \cdot \mathrm{dm}^{-3}$. In the research of Du et al. (2018), oregano (Origanum vulgare) cultivated in the soil was subjected to a 60-day-long exposure to CuNPs and $\mu \mathrm{Cu}$ at different concentrations. During the harvest, copper accumulation, biomass production, nutrient composition and $\mathrm{Cu}$ fractions in the soil were measured. Both CuNPs, and $\mu \mathrm{Cu}$ increased the copper content within the roots and shoots. CuNPs and $\mu \mathrm{Cu}$ had no impact on the shoots' length, malondialdehyde or chlorophyll concentration, but they increased the water content and reduced the shoots' biomass. Both copper nanoparticles and macroparticle copper modified the $\mathrm{Ca}, \mathrm{Fe}, \mathrm{Mg}$ and $\mathrm{Mn}$ content within the roots and shoots. Furthermore, they reduced the starch, total sugar and reducing sugar content within the leaves. The results showed that $\mathrm{Cu}$ nanoparticles/microparticles had an impact on the agronomic and physiological parameters in oregano that might have an impact on human nutrition. Zuverza-Mena et al. (2015), in their research on the impact of copper nanoparticles on coriander (Coriandrum sativum), demonstrated that CuONPs, $\mu \mathrm{CuO}$ and $\mathrm{Cu}$ ions at concentrations of 20 and $80 \mathrm{mg} \cdot \mathrm{kg}^{-1}$ reduced the coriander seed germination index and the cumulation of micro- and macro-elements ( $\mathrm{B}, \mathrm{Zn}, \mathrm{Mn}, \mathrm{Ca}, \mathrm{Mg}, \mathrm{P}, \mathrm{S})$ in the shoots. Moreover, CuNPs at a concentration of $80 \mathrm{mg} \cdot \mathrm{kg}^{-1}$ had a negative impact on the shoots' length. Adams et al. (2017), while studying the impact of copper nanoparticles on wheat seedlings, demonstrated an inhibiting impact of CuNPs and copper ions on the extension of the roots; they changed the line of the root peels cells and supported their differentiation into root hair cells. Trujillo-Reyes et al. (2014) studied the impact of CuNPs and CuONPs at concentrations of 10 and $20 \mathrm{mg} \cdot \mathrm{dm}^{-3}$ on 18-day-long lettuce seedlings (Lactuca sativa). The nanoparticles reduced 
the water content, the roots' length and the dry biomass of lettuce plants. The results indicated an increased catalase activity and a decreased ascorbate peroxidase activity within the roots, which might be related to an observed slight accumulation of copper nanoparticles on these parts of the plants. Moreover, as compared to the control plants, the copper nanoparticles changed the nutritional quality of the lettuce, the treated plants were characterised by a higher $\mathrm{Cu}, \mathrm{Al}$ and $\mathrm{S}$ content and by a lower $\mathrm{Mn}, \mathrm{P}, \mathrm{Ca}$ and $\mathrm{Mg}$ content.

Pradhan et al. (2015) were studying the impact of CuNPs on Mung beans (Vigna radiata) in comparison to macromolecular copper and copper sulphide salt (CS). In order to reduce the toxicity, the CuNPs were closed in a capsule made of polymer (PEG-200, polyethylene glycol). In the biochemical and biophysical analyses of the isolated bean chloroplasts, the CuNPs addition had an impact on the increase of photosynthetic activity of the bean through the modulation of fluorescence emission, phosphorylation, electron transport chain (ETC) and carbon assimilation pathway. CuNPs at doses $0.05,0.1,0.5,1.0 \mathrm{mg} \cdot \mathrm{dm}^{-3}$ had more positive effects than CS in terms of the basic morphology, pigment content and antioxidant activities within the plants. CuNPs showed an increased nitrogen assimilation as compared to CS. At higher doses, it was stated that CS is toxic for the plant system, while CuNPs did not cause any toxicity, including morphological or physiological changes.

Javed et al. (2017) focused on the research of the accumulation of secondary metabolites in medicinal plants through arousing abiotic and biotic stress. In the research, there was an impact of copper and zinc nano-oxide, as well as growth regulators on the regeneration of callus from explants of leaves of Stevia rebaudiana medicinal plant. Samples cultivated on the MS nutrient medium enriched in $10 \mathrm{mg} \cdot \mathrm{dm}^{-3}$ of copper nano-oxidase were characterised by the highest results of the measurement of the total phenolic content (TPC), the total antioxidant capacity (TAC), the total reducing power (TRP) and the ability to capture free radicals. The research also demonstrated that copper nano-oxide is more toxic for Stevia rebaudiana callus than zinc nano-oxide.

\section{THE IMPACT OF PLATINUM NANOPARTICLES ON THE GROWTH OF PLANTS IN THE IN VITRO CULTURES}

There are not many publications on the influence of platinum on tissue plants in in vitro cultures. In the existing research, the effects of nanoplatinum have been oscillating between stimulating and toxic, depending on the metal concentration in the growth medium. Lower doses of platinum, up to $2.5 \mu \mathrm{M}$, had a positive impact on the growth and development of plants; they were causing an increase in the total surface area of the leaves, the roots' length, the amount of fresh and dry matter. In the case of higher concentrations, an inhibiting impact on the growth was observed. High concentrations of platinum $(25 \mu \mathrm{M})$ caused the occurrence of chlorosis and necrosis on the leaves, whereas the roots became discoloured and turned white to light brown, and they were vulnerable to crushing (Gawrońska et al. 2018). In the research of Asztemborska et al. (2015) on the plants from Sinapis alba and Lepidium sativum species, the visible effects of phytotoxicity after the application of platinum nanoparticles were not observed. The nanomaterial had also no impact on the change of the 
plants' colours, the biomass production, the root system or hydration of the tissues. In the experiment, a high platinum accumulation was observed both in the underground and overground parts of the studied plants.

\section{CONCLUSIONS}

In this articles, we gather the knowledge acquired up to now on the interactions of specified nanoparticles - of gold, silver, copper and platinum with plants cultivated in laboratory conditions. The existing research does not allow us to determine unequivocally what impact nanometals have on the plants. The properties that make them unique may have both a negative and positive impact on plants. In a great deal of research, the impact of the nanoparticles on the decrease of the plants' growth and formation of sorter shoots and roots was observed. A high concentration of nanoparticles was also decreasing the chlorophyll content, photosynthesis, transpiration and stomatal conductance rates. The contact of plants with nanoparticles was also manifesting itself by an increased oxidative stress. On the other hand, nanoparticles at appropriate concentrations can be used for improve seed germination, increase growth and plant production as well as their protection and improvement of production of bioactive compounds.

\section{REFERENCES}

Adams J., Wright M., Wagner H., Valiente J., Britt D., Anderson A. 2017. Cu from dissolution of $\mathrm{CuO}$ nanoparticles signals changes in root morphology. Plant Physiol. Bioch. 110, 108-117.

Alexander J.W. 2009. History of the medical use of silver. Surg. Infect. 10(3), 289-292.

Arora S., Sharma P., Kumar S., Nayan R., Khanna P.K., Zaidi M.G.H. 2012. Gold-nanoparticle induced enhancement in growth and seed yield of Brassica juncea. Plant Growth Regul. 66(3), 303-310.

Asharani P.V., Xinyi N., Hande M.P., Valiyaveettil S. 2010. DNA damage and p53 mediated growth arrest in human cells treated with platinum nanoparticles. Nanomedicine 5(1), 51-64.

Asztemborska M., Steborowski R., Kowalska J., Bystrzejewska-Piotrowska G. 2015. Accumulation of platinum nanoparticles by Sinapis alba and Lepidium sativum plants. Water Air Soil Poll. 226(4), 126.

Ball P. 2002. Natural strategies for the molecular engineer. Nanotechnology 13(5), 15-28.

Bansal V., Li V., O'Mullane A.P., Bhargava S.K. 2010. Shape dependent electrocatalytic behaviour of silver nanoparticles. Cryst. Eng. Comm. 12(12), 4280-4286.

Barnard A.S. 2010. Modelling of nanoparticles: approaches to morphology and evolution. Rep. Prog. Phys. 73(8), 086502.

Benn T.M., Westerhoff P. 2008. Nanoparticle silver released into water from commercially available sock fabrics. Environ. Sci. Technol. 42, 4133-4139.

Brunner T.I., Wick P., Manser P., Spohn P., Grass R.N., Limbach L.K., Bruinink A., Stark W.J. 2006. In vitro cytotoxicity of oxidenanoparticles: comparison to asbestos, silica, and effect of particle solubility. Environ. Sci. Technol. 40, 4374-4381.

Chen X., Schluesener H.J. 2008. Nanosilver: a nanoproduct in medicalapplication. Toxicol. Lett. 176, $1-12$.

Cioffi N., Torsi L., Ditaranto N., Tantillo G., Ghibelli L., Sabbatini L., Traversa E. 2005. Copper nanoparticle/polymer composites with antifungal and bacteriostatic properties. Chem. Mater. 17(21), 5255-5262. 
Da Costa M.V.J., Sharma P.K. 2016. Effect of copper oxide nanoparticles on growth, morphology, photosynthesis, and antioxidant response in Oryza sativa. Photosynthetica 54, 110-119.

Du W., Tan W., Yin Y., Ji R., Peralta-Videa J.R., Guo H., Gardea-Torresdey J.L. 2018. Differential effects of copper nanoparticles/microparticles in agronomic and physiological parameters of oregano (Origanum vulgare). Sci. Total Environ. 618, 306-312.

Etxeberria E., Gonzalez P., Pozueta J. 2009. Evidence for two endocytic transport pathways in plant cells. Plant Sci. 177(4), 341-348.

Fazal H., Abbasi B.H., Ahmad N., Ali M. 2016. Elicitation of medicinally important antioxidant secondary metabolites with silver and gold nanoparticles in callus cultures of Prunella vulgaris L. Appl. Biochem. Biotech. 180(6), 1076-1092.

Feichtmeier N.S., Walther P., Leopold K. 2015. Uptake, effects, and regeneration of barley plants exposed to gold nanoparticles. Environ. Sci. Pollut. 22(11), 8549-8558.

Gawrońska H., Przybysz A., Szalacha E., Pawlak K., Brama K., Miszczak A., Gawroński S.W. 2018. Platinum uptake, distribution and toxicity in Arabidopsis thaliana L. plants. Ecotox. Environ. Safe. 147, 982-989.

Gottschalk F., Nowack B. 2011. The release of engineered nanomaterials to the environment. J. Environ. Monitor. 13, 1145-1155.

Grace A.N., Pandian K. 2007. Antibacterial efficacy of aminoglycosidic antibiotics protected gold nanoparticles - A brief study. Colloid. Surface, A 297(1-3), 63-70.

Gunjan B., Zaidi M.G.H. 2014. Impact of gold nanoparticles on physiological and biochemical characteristics of Brassica juncea. J. Plant Biochem. Physiol. 2(3), 133.

Homaee M.B., Ehsanpour A.A. 2015. Physiological and biochemical responses of potato (Solanum tuberosum) to silver nanoparticles and silver nitrate treatments under in vitro conditions. J. Plant Physiol. 20(4), 353-359.

Hossain Z., Mustafa G., Komatsu S. 2015. Plant responses to nanoparticle stress. Inter. J. Molec. Sci. 16(11), 26644-26653.

Javed R., Yucesan B., Zia M., Gurel E. 2017. Elicitation of secondary metabolites in callus cultures of Stevia rebaudiana Bertoni grown under $\mathrm{ZnO}$ and $\mathrm{CuO}$ nanoparticles stress. Sugar. Tech. 20(2), 1-8.

Jeon H.J., Yi S.C., Oh S.G. 2003. Preparation and antibacterial effects of $\mathrm{Ag}-\mathrm{SiO}_{2}$ thin films by sol-gel method. Biomaterials 24(27), 4921-4928.

Kaegi R., Sinnet B., Zuleeg S., Hagendorfer H., Mueller E., Vonbank R., Boller M., Burkhardt M. 2010. Release of silver nanoparticles from outdoor facades. Environ. Pollut. 158, 2900-2905.

Khot L.R., Sankaran S., Mari J., Ehsani R., Schuster E.W. 2012. Applications of nanomaterials in agricultural production and crop protection: A review. Crop Protect. 35, 64-70.

Kostova I. 2006. Platinum complexes as anticancer agents. Recent Pat. Anti-Canc. 1(1), 1-22.

Kumar V., Gileria P., Kumar V., Yadav S.K. 2013. Gold nanoparticle exposure induces growth and yield enhancement in Arabidopsis thaliana. Sci. Total. Environ. 46, 462-468.

Lee K., Lee H., Bae K.H., Park T.G. 2010. Heparin immobilized gold nanoparticles for targeted detection and apoptotic death of metastatic cancer cells. Biomaterials 31, 6530-6536.

Lee W.M., An Y.J., Yoon H., Kweon H.S. 2008. Toxicity and bioavailability of copper nanoparticles to the terrestrial plants mung bean (Phaseolus radiatus) and wheat (Triticum aestivum): plant agar test for water-insoluble nanoparticles. Environ. Toxicol. Chem. 27(9), 1915-1921.

Li X., Ke M., Zhang M., Peijnenburg W.J.G.M., Fan X., Xu J., Zhang Z., Lu T., Fu Z., Qian H. 2018. The interactive effects of diclofop-methyl and silver nanoparticles on Arabidopsis thaliana: Growth, photosynthesis and antioxidant system. Environ. Pollut. 232, 212-219.

Ma X., Geiser-Lee J., Deng Y., Kolmakov A. 2010a. Interactions between engineered nanoparticles (ENPs) and plants: phytophytotoxicity, uptake and accumulation. Sci. Total. Environ. 408(16), 3053-3061.

Ma Y., Kuang L., He X., Bai W., Ding Y., Zhang Z., Zhao Y., Chai Z. 2010b. Effects of rare earth oxide nanoparticles on root elongation of plants. Chemosphere 78(3), 273-279. 
Manikandan M., Hasan N., Wu H.F. 2013. Platinum nanoparticles for the photothermal treatment of Neuro 2A cancer cells. Biomaterials 34(23), 5833-5842.

Mary G., Bajpai S.K., Chand N. 2009. Copper (II) ions and copper nanoparticles-loaded chemically modified cotton cellulose fibers with fair antibacterical properties. J. Appl. Polym. Sci. 113, 757-766.

Mauter M.S., Elimelech M. 2008. Environmental applications of carbon-based nanomaterials. Environ. Sci. Technol. 42(16), 5843-5859.

Mehrian S.K., Heidari R., Rahmani F. 2015. Effect of silver nanoparticles on free amino acids content and antioxidant defense system of tomato plants. Ind. J. Plant Physiol. 20(3), 257-263.

Miralles P., Church T.L., Harris A.T. 2012. Toxicity, uptake, and translocation of engineered nanomaterials in vascular plants. Environ. Sci. Technol. 46(17), 9224-9239.

Mittler R. 2002. Oxidative stress, antioxidants and stress tolerance. Trends Plant Sci. 7(9), 405-410.

Monica R.C., Cremonini R. 2009. Nanoparticles and higherplants. Caryologia 62(2), 161-165.

Mubashir M., Raja N.I., Iqbal M., Sabir S., Yasmeen F. 2017. In vitro seed germination and biochemical profiling of Artemisia absinthium exposed to various metallic nanoparticles. Biotech. 7(2), 101.

Murr L.E. 2009. Nanoparticulate materials in antiquiti: the goog, the bad and the ugly. Mater. Charact. 60, 261-270.

Nair P.M.G., Chung I.M. 2014. Physiological and molecular level effects of silver nanoparticles exposure in rice (Oryza sativa L.) seedlings. Chemosphere 112, 105-113.

Nair P.M.G., Chung I.M. 2015. Physiological and molecular level studies on the toxicity of silver nanoparticles in germinating seedlings of mung bean (Vigna radiata L.). Acta Physiol. Plant. 37(1), 1719.

Narayanan R., El-Sayed M.A. 2005. Catalysis with transition metal nanoparticles in colloidal solution: Nanoparticle Shape Dependence and Stability. J. Phys Chem B. 109, 12663-12676.

Navarro E., Piccapietra F., Wagner B., Marconi F., Kaegi R., Odzak N., Sigg L., Behra R. 2008. Toxicity of silver nanoparticles to Chlamydomonas reinhardtii. Environ. Sci. Technol. 42, 8959-8964.

Nel A., Xia T., Madler L., Li N. 2006. Toxicpotential of materials at the nanolevel. Science 311(5761), 622-627.

Nowack B., Bucheli T.D. 2007. Occurrence, behaviour and effects of nanoparticles in the environment. Environ. Pollut. 150, 5-22.

Nowack B., Krug H.F., Height M. 2011. 120 years of nanosilver history: implications for policy makers. Environ. Sci. Technol. 45(4), 1177-1183.

Ostroumov S.A., Poklonov V.A., Kotelevtsev S.V., Orlov S.N. 2014. Toxicity of gold nanoparticles for plants in experimental aquatic system. Mosc. Univ. Biol. Sci. Bull. 69(3), 108-112.

Poborilova Z., Opatrilova R., Babula P. 2013. Toxicity of aluminium oxide nanoparticles demonstrated using a BY-2 plant cell suspension culture model. Environ. Exp. Bot. 91, 1-11.

Pradhan S., Patra P., Mitra S., Dey K.K., Basu S., Chandra S., Goswami A. 2015. Copper nanoparticle (CuNP) nanochain arrays with a reduced toxicity response: a biophysical and biochemical outlook on Vigna radiata. J. Agr. Food Chem. 63(10), 2606-2617.

Rajeshwari A., Suresh S., Chandrasekaran N., Mukherjee A. 2016. Toxicity evaluation of gold nanoparticles using an Allium cepa bioassay. RSC Advances 6(29), 24000-24009.

Ramyadevi J., Jeyasubramanian K., Marikani A., Rajakumar G., Rahuman A.A. 2012. Synthesis and antimicrobial activity of copper nanoparticles. Mater. Lett. 71, 114-116.

Rani P.U., Rajasekharreddy P. 2011. Green synthesis of silver-protein (core-shell) nanoparticles using Piper betle L. leaf extract and its ecotoxicological studies on Daphnia magna. Colloids Surf. A: Physicochem. Eng. Asp. 389(1), 188-194.

Rani P.U., Yasur J., Loke K.S., Dutta D. 2016. Effect of synthetic and biosynthesized silver nanoparticles on growth, physiology and oxidative stress of water hyacinth: Eichhornia crassipes (Mart) Solms. Acta Physiol. Plant. 38(2), 58. 
Rico C.M., Majumdar S., Duarte-Gardea M., Peralta-Videa J.R., Gardea-Torresdey J.L. 2011. Interaction of nanoparticles with edible plants and their possible implications in the food chain. J. Agric. Food Chem. 59(8), 3485-3498.

Roco M.C. 2003a. Broader societal issue of nanotechnology. J. Nanopart. Res. 5(3-4), 181-189.

Roco M.C. 2003b. Nanotechnology: convergence with modern biology and medicine. Curr. Opin. Biotech. 14, 337-346.

Rosa G. de la, García-Castañeda C., Vázquez-Núñez E., Alonso-Castro Á.J., Basurto-Islas G., Mendoza Á., Molina C. 2017. Physiological and biochemical response of plants to engineered NMs: Implications on future design. Plant Physiol. Bioch. 110, 226-235.

Rui M., Ma C., Tang X., Yang J., Jiang F., Pan Y., Xiang Z., Hao Y., Rui Y., Cao W., Xing B. 2017. Phytotoxicity of silver nanoparticles to peanut (Arachis hypogaea L.): physiological responses and food safety. ACS Sustain. Chem. Eng. 5(8), 6557-6567.

Ruparelia J.P., Chatterjee A.K., Duttagupta S.P., Mukherji S. 2008. Strain specificity in antimicrobial activity of silver and copper nanoparticles. Acta Biomat. 4(3), 707-716.

Savithramma N., Ankanna S., Bhumi G. 2012. Effect of nanoparticles on seed germination and seedling growth of Boswellia ovalifoliolata an endemic and endangered medicinal tree taxon. Nano Vision 2(1), 2.

Schmid G., Corain B. 2003. Nanoparticulated gold: syntheses, structures, electronics, and reactivities. Eur. J. Inorg. Chem. 17, 3081-3098.

Sewelam N., Kazan K., Schenk P.M. 2016. Global plant stress signaling: reactive oxygen species at the cross-road. Front. Plant Sci. 7, 187.

Sharma P, Bhatt D., Zaidi M.G.H., Saradhi P.P., Khanna P.K., Arora S. 2012. Silver nanoparticlemediated enhancement in growth and antioxidant status of Brassica juncea. Appl. Biochem. Biotechnol. 167, 2225-2233.

Shaw A.K., Hossain Z. 2013. Impact of nano-CuO stress on rice (Oryza sativa L.) seedlings. Chemosphere 93(6), 906-915.

Shi J., Peng C., Yang Y., Yang J., Zhang H., Yuan X., Hu T. 2014. Phytotoxicity and accumulation of copper oxide nanoparticles to the Cu-tolerant plant Elsholtzia splendens. Nanotoxicology 8(2), 179-188.

Shokri S., Babaei A., Ahmadian M., Arab M.M., Hessami S. 2013. The effects of different concentrations of Nano-Silver on elimination of bacterial contaminations and phenolic exudation of Rose (Rosa hybrida L.) in vitro culture. VIII International Symposium on in Vitro Culture and Horticultural Breeding 1083, 391-396.

Sondi I., Salopek-Sondi B. 2004. Silver nanoparticles as antimicrobial agent: a case study on E. coli as a model for Gram-negative bacteria. J. Colloid. Interf. Sci. 275(1), 177-182.

Sosan A., Svistunenko D., Straltsova D., Tsiurkina K., Smolich I., Lawson T. Subramanian S., Golovko V., Anderson S., Sokolik A., Colbeck I., Demidchik V. 2016. Engineered silver nanoparticles are sensed at the plasma membrane and dramatically modify the physiology of Arabidopsis thaliana plants. The Plant J. 85(2), 245-257.

Thwala M., Musee N., Sikhwivhilud L., Wepener V. 2013. The oxidative toxicity of $\mathrm{Ag}$ and $\mathrm{ZnO}$ nanoparticles towards the aquatic plant Spirodela punctuta and the role of testing media parameters. Environ. Sci. Proc. Impacts 15, 1830.

Torney F., Trewyn B.G., Lin V.S.Y., Wang K. 2007. Mesoporous silica nanoparticles deliver DNA and chemicals into plants. Nature Nanotechnol. 2(5), 295.

Trujillo-Reyes J., Majumdar S., Botez C.E., Peralta-Videa J.R., Gardea-Torresdey J.L. 2014. Exposure studies of core-shell $\mathrm{Fe} / \mathrm{Fe} 3 \mathrm{O} 4$ and $\mathrm{Cu} / \mathrm{CuO}$ NPs to lettuce (Lactuca sativa) plants: are they a potential physiological and nutritional hazard? J. Hazard. Mater. 267, 255-263.

Vaidyanathan R., Kalishwaralal K., Gopalram S., Gurunathan E. 2009. Nanosilver - the burgeoning therapeutic molekule and its green synthesis. Biotechnol. Adv. 27, 924. 
Van Breusegem F., Dat J.F. 2006. Reactive oxygen species in plant cell death. Plant Physiol. 141(2), 384-390.

Vázquez-Victorio, G., Acevedo-Salas U., Valenzuela R. 2013. Microwave absorption in nanostructured spinel ferrites, in: Ferromagnetic resonance. Theory and applications. Ed. O. Yalcin. London, InTech Open, 169-194.

Wang M., Wang L., Wang G., Ji X., Bai Y., Li T., Li J. 2004. Application of impedance spectroscopy for monitoring colloid Au-enhanced antibody immobilization and antibody-antigen reactions. Biosens. Bioelectron. 19(6), 575-582.

Wang X., Yang X., Chen S., Li Q., Wang W., Hou C., Wang S. 2016. Zinc oxide nanoparticles affect biomass accumulation and photosynthesis in Arabidopsis. Front. Plant Sci. 6, 1243.

Yoon K.Y., Byeon J.H., Park J.H., Hwang J. 2007. Susceptibility constants of Escherichia coli and Bacillus subtilis to silver and copper nanoparticles. Sci. Total Environ. 373(2-3), 572-575.

Zhao L., Peng B. Hernandez-Viezcas J.A., Rico C., Sun Y., Peralta-Videa J.R. 2012. Stress response and tolerance of Zea mays to $\mathrm{CeO}_{2}$ nanoparticles: cross talk among $\mathrm{H}_{2} \mathrm{O}_{2}$, heat shock protein and lipid peroxidation. ACS Nano 6, 9615-9622.

Zhong C.J., Maye M.M., Luo J., Kariuki N. 2004. Nanoparticles in catalysis, in: Rotello V Nanoparticles: building blocks for nanotechnology. New York, Kluwer Academics, 113-140.

Zhou X., Liu C., Zhang Z., Jiang L., Li J. 2005. A novel nanogold multilayer constructed by Langmuir-Blodgett and self-assembly techniques. J. Colloid Interf. Sci. 284(1), 354-357.

Zuverza-Mena N., Armendariz R., Peralta-Videa J.R., Gardea-Torresdey J.L. 2016. Effects of silver nanoparticles on radish sprouts: root growth reduction and modifications in the nutritional value. Front. Plant Sci. 7, 90.

Zuverza-Mena N., Medina-Velo I.A., Barrios A.C., Tan W., Peralta-Videa J.R., Gardea-Torresdey J.L. 2015. Copper nanoparticles/compounds impact agronomic and physiological parameters in cilantro (Coriandrum sativum). Environ. Sci-Proc. Imp. 17(10), 1783-1793.

\section{NANOCZĄSTECZKI METALI - ICH WYKORZYSTANIE ORAZ WPŁYW NA ROŚLINY ROSNĄCE W WARUNKACH LABORATORYJNYCH}

Streszczenie. Nanotechnologia cieszy się coraz większym zainteresowaniem naukowców na całym świecie. Nanocząsteczki różnią się od klasycznego materiału, z którego są wytwarzane, tym, że poniżej pewnych rozmiarów zmieniają właściwości fizyczne i chemiczne. Dzięki tym cechom są stosowane zarówno $w$ badaniach naukowych, medycynie, jak i w przemyśle, a $\mathrm{w}$ ostatnich latach również $\mathrm{w}$ rolnictwie. W zależności od rodzaju metalu oraz wielkości cząsteczki ich wpływ na rozwój roślin jest jednak zróżnicowany. W niniejszej pracy zebrano dotychczas zdobytą wiedzę na temat interakcji nanocząsteczek złota, srebra, miedzi i platyny z roślinami uprawianymi w warunkach laboratoryjnych. Dotychczasowe badania nie potrafia jednoznacznie wskazać, jaki wpływ na rośliny wywierają nanometale. Właściwości, które sprawiają, że są one unikatowe, mogą oddziaływać na rośliny zarówno negatywnie, jak i pozytywnie. W wielu badaniach zaobserwowano wpływ nanocząsteczek na obniżenie wzrostu roślin oraz tworzenie się krótszych pędów i korzeni. Wysokie stężenia nanocząsteczek obniżają również zawartość chlorofilu, tempo fotosyntezy, transpiracji i przewodnictwa szparkowego. Kontakt roślin z nanocząsteczkami objawia się również zwiększonym stresem oksydacyjnym, w wyniku którego $w$ tkankach roślinnych obserwowano nadprodukcję reaktywnych form tlenu uszkadzających lipidy błony komórkowej oraz DNA. W przypadku dodatku nanocząsteczek do podłoży hodowlanych w kulturach in vitro często obserwowano wolniejszą regenerację roślin i ich zamieranie. Przeprowadzając wiele badań z użyciem nanocząsteczek, naukowcy doszli do wniosku, że odpowiednie ich stężenia mogą być stosowane w celu poprawienia kiełkowania nasion, zwiększenia wzrostu i plonów roślin, a także ich ochrony i polepszenia produkcji bioaktywnych związków.

Słowa kluczowe: nanotechnologia, nanocząsteczki metali, regeneracja roślin. 
